\title{
Remembrance of Petre T. Frangopol (1933-2020) the promoter of scientometrics in Romania
}

\author{
Gheorghe Benga ${ }^{1,2,3}$
}

Received: 1 November 2021 / Accepted: 3 November 2021 / Published online: 28 December 2021

(c) Akadémiai Kiadó, Budapest, Hungary 2021

\begin{abstract}
The article is an obituary aimed to pay tribute to Petre T. Frangopol, a brilliant Romanian scientist (chemist and biophysicist). He had many fields of interest: Chemistry, Radiochemistry, Physical Organic Chemistry, Biophysical Chemistry, Biophysics, Medical Physics, Archaeometry, Oceanography, History of Chemistry in Romania. However, I consider Petre T. Frangopol as the main promotor of Scientometrics in Romania since he published a lot of articles and books in this field. The achievements of Petre T. Frangopol were recognized by many prizes and distinctions received throughout his life, including the election in The Romanian Academy. He was also a man of great character and an unforgettable friend (Petrache).
\end{abstract}

Gheorghe Benga

gbgbenga@gmail.com

1 Cluj-Napoca Branch, Romanian Academy, 9 Republicii St., 400015 Cluj-Napoca, Romania

2 Academy of Medical Sciences, 1 Ion C. Brătianu Boulevard, 030167 Bucharest, Romania

3 School of Life and Environmental Sciences, Building G08, University of Sydney, Sydney, NSW 2006, Australia 


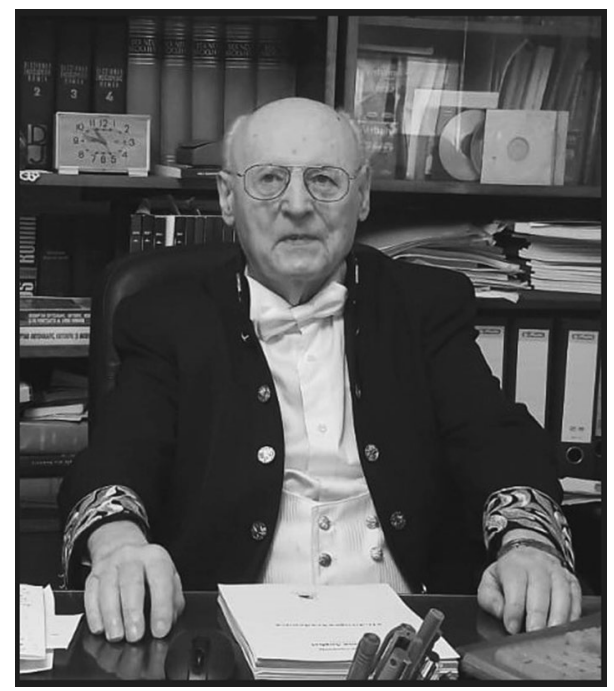

Petre T. Frangopol, a brilliant Romanian chemist and biophysicist, the main promoter of scientometrics in Romania, has passed away in December 2020, a very sad event for all colleagues who had the chance to know him. This obituary is aimed to pay tribute to a man of great character and an unforgettable friend (Petrache). Some of the Romanian scientists who had the chance to know him well (including myself) were invited speakers at a Meeting of The Romanian Academy (R.A.) dedicated to P.T. Frangopol's 85th anniversary cellebrated on October 8, 2018. The proceedings of this Meeting were published in the 7th volume of a series assembled by P.T. Frangopol dedicated to the analysis of research and higher education in Romania (Frangopol, 2019). He said at the Meeting: „The family saga, heard since my childhood, influenced my character and encouraged me to assert myself in the chosen profession" (Frangopol, 2019, p. 99). Petre Frangopol was born on 26 May 1933 in Constanţa, being the son of Theodor (born in Constanţa) and Ecaterina (born in Varna, Bulgaria). Both parents were Greeks. Constanţa, a city located in a historical region of Romania called Dobruja (Dobrogea), on the Black Sea coast, is considered to be among the oldest continuously inhabited cities of Romania (Anghel, 2019). It was founded around 600 BC (historically known as Tomis). Ovid, a great Roman poet (banished here in AD 8 by the Emperor Augustus) spent in Tomis the remaining eight years of his life. Ovid laments his exile in some poems (Tristia and Epistulae ex Ponto). The statue of Ovid is located today in Constanţa in front of the Museum of National History (the former City Hall). A number of inscriptions found in the city and its vicinity show that Constanţa lies where Tomis once stood. Some of these inscriptions are now preserved in the British Museum in London. Tomis was later renamed Constantiana in honour of Constantia, the half-sister of Roman Emperor Constantine the Great (274-337). The earliest known usage of the city name Constantia was in 950. Dobrogea became part of Wallachia (the Southern province of Romania) under Mircea I, a famous Romanian Voivode of Walachia, also called Mircea the Elder (in Romanian „Mircea cel Bătrân”), who reigned from 1386 until his death in 1418. During his reign Wallachia controlled the largest area in its history. Mircea the Elder is considered one of the great rulers of his era, and starting in the nineteenth century Romanian historiography also referred to him as „Mircea the Great”. Constanţa fell under 
the Ottoman rule around 1419. In the subsequent centuries Constanţa declined becoming a village called Kiustengé (the Turkish name). In 1878, after the Romanian War of Independence, Dobrogea was ceded by the Ottoman Empire to Romania. Constanţa became Romania's main seaport and transit point for much of Romania's exports. The Port of Constanţa is now the largest one on the Black Sea, and one of the largest ports in Europe. Constanţa is the capital of Constanţa County and the largest city in Dobrogea. It has a population of more than 300,000 inhabitants, making it the fifth most populous city in Romania (https:// en.wikipedia.org/wiki/Constan\%C8\%9Ba).

Petre T. Frangopol's great-grandparents were Greeks from a village in Bulgaria called Mesemvria (Nesebăr of today), where the Greeks (mainly shepherds) formed 100\% of the population. After an ethnic cleansing performed by Bulgarians in 1860, all inhabitants from this village sold their properties and came with their flocks of sheep to Dobrogea, namely to Kiustengé, a village with thatched huts, inhabited by lots of poor people. Petrache's great-grandparents were teenagers when came to Kiustengé. As described in some books of German and French medical officers who accompanied the Turkish troops during the Crimeean War (1853-1856), Dobrogea looked like a desert area, with scorched earth due to many wars. The Greeks from Kiustengé have developed a new life from scratch. Working hard, with a strong desire to contribute to the developement of the country which offered them not only a shelter, but also the citizenship, many Greeks became honorable citizens of Constanţa. Undoubtly, these people, poor and brave, managed to carve out a new life on the Dobrogean land, after they have been expelled from their homes in Bulgaria. Petre T. Frangopol was very proud of the saga of his family. He was born in 1933 in a house located on a street named after a Roman Emperor (Marcus Aurelius) and the windows of the house opened onto The Sea St. He confessed (Frangopol, 2018, p. 97) that his longevity was due not only to his genes, but also to the city in which he was born. The Sun and The Sea (present a few meters from his home) were second nature to him. The beach soccer and volleyball played until dark with all children from neighborhood, as well as the long discussions about books and movies, led to an athmosphere of friendship and trust, a solidarity that was above ethnicity or religion. Petrache confessed that all such interactions were of great help for him in life. The athmosphere was also described by his best friend Paul (Puiu) Diaconescu.

Petre T. Frangopol received a solid and complex education in Romania since childhood (family education), continuing with public education of all grades: kindergarten, primary school, secondary and high school, university and postgraduate studies. Both Petrache and Puiu had best memories of Mrs. Gheţu, an unusual gentle kindergarten educator. When Petrache reached the age of going to school, his father took him to go on foot, in the first day, to the Romanian primary school. On the way they passed in front of the Greek school (where all teaching was done in the Greek language). His father told him: ,...you have a Greek name, but you should know that you are Romanian, like your father, who fought in the first world war for this country, which you should love as myself; your place is not in the Greek school." (Frangopol, 2019, p. 98). In addition to the good genes Petrache's parents had a positive influence during his formative years, providing an environment allowing his qualities to develop: sharp intelligence, determination for learning and studies, qualities for leadership and mentoring.

Petrache recalls all years of primary, secondary and high school studies (Frangopol, 2019, pp. 179-196). In the primary school (between 1940 and 1944, during The Second World War), he had a very good teacher, Mr. Gheorghe Enăchescu, perceived by the pupils (a multiethnic class) like a family member. He taught his pupils a lot of things, from basic notions to more advanced knowledge: reading (beginning with the alphabet and continuing 
with some works of the classics of Romanian literature), writing (including calligraphy; Petrache had a beautiful handwriting until the end of his life), arithmetics (beginning with the multiplication table), history, geography (using maps and compass!). Everything was properly explained being learnt for life. Mr. Enăchescu played a very important role in the lives of pupils, giving them a patriotic education, with appreciation of the heroes dead in the war (he was on the front in 1941). Above all Mr. Enăchescu taught his pupils the „pleasure of learning” (Frangopol, 2019, p. 183). After graduating from primary school Petrache studied the subsequent classes (between 1944 and 1951) at the oldest and most prestigious high school for boys from Constanţa, opened in 1920's, called „Mircea cel Bătrân”, which was awarded in 1938 the title of ,School of excellence”. It was located in a beautiful building, which between 1944 and 1948 was requisitioned by the Red Army. In this period of life Petrache and his friend Puiu discovered the pleasure of reading books (which were rather expensive during the war and subsequent years and their parents could not buy them). Eager to read literature, the two teenagers paid weekly visits to the Public Library of Constanţa, borrowing various books. The chief of the library, Mrs. Elena Cămară, a very distinguished lady, treated the boys very politely, in the same way in which she behaved with adult readers. She advised them which books are suitable to their age and represent really essential reading. The boys got a comprehensive general culture, reading 4000-5000 pages per week (they were in competition!). In addition, the professors of Romanian and French language from the high school taught the boys the grammar and the classics of Romanian and universal literature. As no higher education institution existed in those years, The „Mircea cel Bătrân” high school was considered to be „The University of Constanţa" (Anghel, 2019, p. 225). The majority of professors obtained Ph.D. titles from German or French universities. Many cultural events took place all over the year in the school. The building had a performance hall, where not only the school year celebrations took place, but also public events: conferences of great scientists and writers, theater performances etc. Petrache described accurately (Frangopol, 2019, pp. 194-197), the imposing figures of: professors of language and literature, such as Ilarie Reit (from a family of Transylvanian Saxons, called saşi in Romanian), who was very rigorous in teaching the grammar of Romanian language and very severe with students; Grigore Sălceanu (a very calm, olimpian figure, a consecrated poet), teaching French; the professors of mathematics Rizescu and Ion Vodă, excellent educators, closed to students. Sometimes Puiu and Petrache, who were reading so much literature, neglected the mathematics and the professor Ion Vodă (the class leader) was worried that Puiu and Petrache will not pass the tough entrance examination for the last classes of the high school; however, the boys surprized their professors and colleagues by the high marks they got. The benefit from the advice of Mrs. Cămară and of professors of languages and literature was very great. Puiu became journalist and writer. Petrache acquired the qualities of an excellent scientific writer (books and papers, articles in newspapers) and a broad humanistic culture, including Greek mythology and an excellent knowledge of the French language.

P.T. Frangopol graduated from high school in 1951 and choosed to become a chemist, following the example of some members of his family. He studied Industrial Chemistry at Iaşi Polytechnic University, a prestigious university (graduating in 1956). He received his $\mathrm{Ph} . D$. in 1968 at another prestigious university, Timişoara Polytechnic, working on the stable free radicals of diaryl-nitrogen under the supervision of Giorgio Ostrogovich, a famous Professor.

Petre T. Frangopol recalls (Frangopol, 2019, p. 249): „I have no idea how much I would have achieved in life if I would have not encountered the scientist Horia Hulubei, ... He had 
unique qualities: generosity, trust in the young persons, with whom he discussed in such a way as they had the feeling of being responsible coworkers, not simple executors".

In 1956 a new Soviet nuclear reactor (cyclotron and betatron) was installed in BucureştiMăgurele, Romania becoming the 7th country in the world having a nuclear reactor. A new Institute of Atomic Physics (in Romanian Institutul de Fizică Atomică, abbreviated as IFA) was founded in Bucureşti-Măgurele, under aegis of R.A. Academician Horia Hulubei, a great scientist, became the first Director of IFA. He was born in Iaşi, graduated in 1926 from Faculty of Sciences (Section physics-chemistry) at Iaşi University (called today University „Alexandru Ioan Cuza”, abbreviated as UAIC). H. Hulubei received his Ph.D. in experimental physics in 1933 from Paris-Sorbonne University where his advisor was Professor Jean Perrin (1926 Nobel Prize in Physics). Between 1927 and 1938, H. Hulubei worked alternately in the laboratory of Perrin in Paris and at Iași University (where he established the first Laboratory of the Structure of Matter in Romania). He became full Professor at Iași University and București University (where he was Rector between 1941 and 1944 and later Professor of Atomic Physics in the Department of Atomic and Nuclear Physics of Faculty of Physics). Elected corresponding member of R.A. in 1937 and titular member in 1946, Hulubei was stripped of membership in 1948 by the new communist regime. In 1955 he was restored to R.A., becoming Director of the Institute of Physics of R.A., later the first Director (1956-1968) and Founder of IFA (Frangopol, 2012; see also https://en.wikipedia.org/wiki/Horia_Hulubei).

P. T. Frangopol presented the history of IFA (Frangopol, 2018), with the problems that had to be quickly solved: the education of personnel qualified in the field of atomic and nuclear physics and the foundation of laboratories specialized in these domains. In order to solve the problem of education, in 1956-1957 a special one-year program of studies under the aegis of IFA was organized. The program included 80 students selected by competition from among the graduates of different faculties of physics, chemistry and engineering of Romanian Universities or Polytechnics. The students were then divided into four groups of 20 each, assigned to: radiochemistry, electronics, biology and medicine. The corresponding collectives newly formed in 1957 were asigned either at IFA or at laboratories in universities, research institutes and in factories.

On the other hand, three new laboratories were set up at IFA: The Laboratory of Radiochemistry and Nuclear Chemistry (LRNC), the Laboratory of Radioactive Isotopes prepared in the Nuclear Reactor (LRNR) and the Laboratory of Labelled Organic Compounds (LLOC). The LRNC was founded in 1956 by Dr. Silvia Ionescu, who was invited by Hulubei in 1955 as Senior Researcher at The Institute of Physics of R.A. She had received her Ph.D. in physical chemistry in 1932 from the Kaiser Wilhelm Universität under the supervision of Max Bodenstein and Walter Nernst (Frangopol, 2018, p. 393). Educated in the German rigorous spirit of scientific research, implying discipline, perseverance and meticulousness, Dr. Silvia Ionescu set up from scratch the LRNC, with equipment for protection against ionizing radiation, for production of radioactive isotopes and for studies of the chemical effects of ionizing radiations and of their various practical (economical) applications. Dr. Silvia Ionescu (Chief of LRNC) and several groups coordinated by young and capable researchers (Maria Fiti, Irina Negoescu, Tudor Costea, Olimpiu M. Constantinescu, Irina N. Plonski) published several monographs and many articles in prestigious international journals and obtained also many patents. Their publications attracted the interest of prominent foreign scientists. Professor A.G. Maddock (from Cambridge University, a well-known researcher in the field and Editor-in-Chief of Nature) came to IFA to meet the group of T. Costea, who suddenly started to publish papers in top journals. Maddock visited the laboratories, attended the seminars, being surprized by the large group of 
young researchers, confirming in the end that the level of research in the field is similar with that in the most advanced countries.

The LRNR was led by Professor Nachman. This laboratory included a group of three chemists working in the building of the nuclear reactor. The coordinator of the group was Tiberiu (Tibor) Braun, a young researcher who graduated in 1953 from Faculty of Chemistry of „Victor Babeş” University Cluj and worked at IFA between 1956 and 1963 as principal physico-chemist. Frangopol () expressed on several occasions his admiration for Tibor, who stood out for the originality of his research. Together with his coworkers the group obtained soon the results in the top of the field, such as an original method of titration with radioactive isotopes, which was suitable for automation. The method was the object of several articles published in prestigious journals (Braun et al., 1958; Galateanu et al., 1960; Maxim et al., 1959). Tibor Braun has also contributed to researches regarding the action of nuclear radiation upon some surface properties (chemisorption of gases, catalytic activity). The results were published in Nature (Braun \& Maxim, 1961; this appears to be the first article published in Nature by researchers from IFA) and other journals (Maxim \& Braun, 1963; Nachman et al., 1961). In 1963 Tibor emigrated to Hungary, where he obtained his Ph.D. and D.Sc. degrees, becoming one of the greatest scientists in the world in the fields of chemistry and scientometrics (one of the pioneers of this science). Petre maintained for all his life the scientific and humane relations with Tibor, presenting him to Romanian and foreign scientists. In addition, Petre was very happy to witness the ceremonies of the award of DhC titles to Tibor by Romanian Universities (,Vasile Goldiş” Western University Arad, Technical University Cluj-Napoca). I was also very happy to witness the award of the title in Cluj-Napoca, when Petre presented a splendid LAUDATIO (Frangopol, 2006a), as well as to vote (in Bucharest) the election of Professor Tibor Braun as Honorary Member of Romanian Academy.

From 1957 to 1963 P. T. Frangopol was Staff member, Laboratory of Organic Chemistry (chaired by Academician Costin D. Neniţescu) at Bucureşti Polytechnical Institute, being paid by IFA and having research topics of IFA. Petrache recalls (Frangopol, 2019, p. 251) that one day was invited by Horia Hulubei for a discussion. The great scientist, talking very kindly, with a soft Moldavian accent, asked him to take a temporary absence from the laboratory of Professor Neniţescu to come to IFA to set up a Laboratory of Labelled Organic Compounds (LLOC), i. e. a laboratory for the preparation of organic compounds labelled with radioactive iodine $\left({ }^{131} \mathrm{I}\right)$ and other (radioactive and stable) isotopes. The technology would be further used by technicians hired specially for the production of these isotopes. Afterwards Petre was supposed to return to the laboratory of Neniţescu. Petre appreciated the position of Professor Hulubei of asking him, not giving him an order: „I emphasize that I have been confronted in this technological implication in a field absolutely novel for me as a laboratory experience, with no mentor to supervise me and no visit abroad to get acquainted with the field". Academician Horia Hulubei had in mind for Petre T. Frangopol to found the LLOC together with Alexandru T. Balaban. Both of them graduated the special 1956-1957 program of studies in radiochemistry and nuclear technology organized under aegis of IFA, being assigned to radiochemistry (and to the cyclotron collective). A. T. Balaban was a young lecturer in the Laboratory of Organic Chemistry chaired by Academician Neniţescu (who also supervised Balaban's Ph.D. work). In parallel, Balaban was hired at IFA in 1956. However, Academician Neniţescu asked Alexandru to fulfill all his duties as lecturer (seminars and laboratory work with students). Under these conditions, Petre was forced to set up alone the laboratory. Such a laboratory did not exist previously in Romania. Petre has not received an adequate space for the laboratory, but a huge empty room, a corridor in the basement, several meters below ground. There it was installed a 
hood, projected by Petre and made by excellent craftsmen (hired at IFA from the Bucureşti „Malaxa” factories). After 7 months the group succeeded to prepare, for the first time in Romania, ${ }^{131}$ I (widely used afterwards for treating diseases of the thyroid). The article describing the preparation was published in Revista de Chimie (Bucureşti) (Chiotan et al., 1961) and, to the surprize of authors, has been translated in English and published in International Chemical Engineering (USA), 2, 357, 1962. This indicated the interest of Americans in monitoring the activity of IFA.

IFA became a multidisciplinary center of excellence (Frangopol, 2018). In the first 6 years after its foundation, over 80 scientific articles have been published by researchers at IFA. Frangopol and Balaban were among the best young researchers of IFA. They performed successful studies aimed to solve important practical problems. An important line of research was the preparation and investigation of stable free radicals for studies of Electron Spin Resonance (ESR), using the ART-6 ESR spectrometer produced at IFA. It was first necessary to prepare the stable free radical 1,1-diphenyl-2-picrilhydrazyl (DPPH), which is used as standard of the position and intensity of ESR signals (Balaban et al., 1961). This was the starting point for the development of a domain of basic research at IFA. Other stable free radicals have been prepared, many of them with the essential help of Mioara Frangopol, the distinguished wife of Petre T. Frangopol. Several articles were published in prestigious journals (Tetrahedron, Journal of Chemical Society, Journal of Organic Chemistry, Isotopes and Radiation Technology, Revue Roumaine de Physique, Revue Roumaine de Chimie). These publications have been reviewed by A.T. Balaban (2012). Moreover, collaboration of Petre and Mioara Frangopol with foreign scientists has started (Frangopol et al., 1973). The work on stable free radicals of the group at IFA gained international recognition, being cited in well known books by foreign researchers (Forrester et al., 1968; Nonhebel \& Walton, 1974; Rozantzev, 1970, 1972).

P.T. Frangopol recalls further (Frangopol, 2019, pp. 250-252): „There were hard times, with obstacles at every step; for example, it was required to ask permission and present a translation in Romanian of each article intended to be published in journals abroad. In addition, we did not have all reagents necessary for chemical syntheses, so that sometimes we asked foreign colleagues to send some substances as gifts. I emphasize that for me, at IFA everything had to be started from scratch...We, at IFA, had to learn ourselves to get a specialized culture, by individual readings in the library of IFA, considered to be one of the best libraries belonging to a scientific institute in the world, as was written in an article published in the USA: Kertesz, F. (1973). Journal of Chemical Documentation, 13(1), 16-20. The author, Francisc Kertesz, from Oak Ridge National Laboratory (ORNL), visited IFA following my invitation (after I lectured at ORNL)".

P.T. Frangopol obtained financial support for work in Canada (Post Doctoral Fellow, National Research Council, Ottawa, Ontario, 1969-1970), USA (Post Doctoral Research Associate, with a NASA contract at the George Washington University, Department of Chemistry, Washington, D.C., 1970-1971), and Germany (Dozentenstipendium, Humboldt Foundation, 1972). He was also cited in many articles in leading (mainstream) journals and books published by well known publishers. P.T. Frangopol was invited to present lectures (as plenary lecturer or key speaker) at many Scientific events, Universities, and Institutions around the world: USA (Gordon Conferences, Argonne National Laboratory, Brookhaven National Laboratory, George Washington University, Washington DC, Colorado University at Boulder, University of Illinois Urbana etc.), EUCHEM Conferences, Germany (Marburg/Lahn University, German Chemical Societies Annual Meetings), Sweden (Umeå University, Stockholm University), France (Centre d'Etudes Nucleaires de Grenoble et de Saclay), Belgium (Leuven University), Slovakia (Bratislava University), Greece (Athens, 
Thessaloniki, Patras and Ioannina Universities), former USSR (Novosibirsk Institute of Organic Chemistry, Moscow Institute of Chemical Physics) etc.

P.T. Frangopol received many offers to establish abroad, however he returned to IFA, since he was Chief of a laboratory founded and equipped by him at international standards, with technologies of preparation and techniques developed for the first time in Romania. Unfortunately, his laboratory was completely destroyed by fire during the 1977 earthquake.

In 1976 IFA was reorganized, the Laboratories of Physics became institutes and the name of IFA was changed in the „Horia Hulubei” National Institute for Research \& Development in Physics and Nuclear Engineering (in Romanian Institutul de Cercetare-Dezvoltare pentru Fizică şi Inginerie Nucleară „Horia Hulubei”, abbreviated as IFIN-HH). The second working period of P.T. Frangopol at IFA has begun (1977-1990). In the new conditions he organized a Center of Radiochemical Production. He had again to start everything from scratch, beginning with documentation, project, procurement and installation of the necessary equipment, development of technologies, finding the space for the Laboratory for Production of Radioactive Isotopes $\left({ }^{32} \mathrm{P},{ }^{45} \mathrm{Ca},{ }^{59} \mathrm{Fe},{ }^{35} \mathrm{~S},{ }^{192} \mathrm{Ir},{ }^{99 \mathrm{~m}} \mathrm{Tc}\right)$ to be used in industry, agriculture, biology and especially in medicine. He had to also find the sources of self-financing. The results of researches had to have direct economic applications, as no financial support from the budget of Romania was provided, according to the policy of communist regime before 1989.

P.T. Frangopol extended later his activity, from organic physical-chemistry and radiochemistry, to biophysical chemistry and biophysics. He was the editor of the first annual publication of biophysics in Romania: Seminars in Biophysics, a series of 6 annual volumes (1985-1990) published in English by IFA. In addition, P.T. Frangopol initiated and managed an extended program of biophysical studies on the interaction of medicines with cell membranes, financed by the Ministry of Chemical Industry. The program involved groups of researchers from Bucharest, Cluj-Napoca and Iaşi.

I met Petre T. Frangopol for the first time in 1976, when he came to the Department of Biochemistry, Faculty of Medicine, Institute of Medicine and Pharmacy Cluj-Napoca (today "Iuliu Haţieganu" University of Medicine and Pharmacy, Cluj-Napoca, abbreviated as UMF Cluj-Napoca), where I was a young Lecturer. Petre introduced himself and said that he was the leader of a group of researchers from IFA and made a proposal to collaborate with him, since he believed we had mutual research interests in studies using spin labels. He had heard that I had just returned from UK, after 12 months of post-doc work in the laboratory of Professor Dennis Chapman, a well-known scientist in the field of biological membranes. My project involved the study of protein-lipid interactions in biological membranes using several techniques, including NMR, spin label ESR etc. I published several articles on these topics with foreign scientists (Benga, 1985, 1988, 1989; Benga \& Chapman, 1976; Benga \& Holmes, 1984; Benga \& Strach, 1975) and with Vasile V. Morariu, a former high school coleague and an excellent Romanian scientist, who was Researcher at Institute of Molecular and Isotopic Technology Cluj-Napoca (in Romanian Institutul de Tehnologie Izotopică şi Moleculară, abbreviated as ITIM) (Benga \& Morariu, 1977; Morariu \& Benga, 1977).

I was honoured that such an outstanding scientist as Petre T. Frangopol (11 years older than me, with so many accomplishments) was inviting me to collaborate with him. After visiting his laboratory in București-Măgurele, I realized that that actually at IFA there was the "Professor Petre T. Frangopol and Dr. Mioara Frangopol group". Petrache was really a world-class scientist, however Mioara also impressed me deeply, by her competence as a scientist, by her intelligence and by her humane qualities. Mioara was a strong support for Petrache. She always found the best ways to perform excellent laboratory work even if the 
conditions were not as good as in laboratories from abroad. A very fruitful collaboration started between the "Frangopol group" in București-Măgurele and the two groups in ClujNapoca: Benga's group at UMF Cluj-Napoca (where I was nominated in 1978 as Chief of the new Discipline of Cell Biology, abbreviated as DCB) and V.V. Morariu's group at ITIM Cluj-Napoca. We published many papers over several decades (Benga et al., 1983a, b, c, 2008; Sholle et al., 1980). In addition, it was for us, the people from Cluj-Napoca, the chance of becoming close friends to Petrache Frangopol.

I have learnt a lot of things from him, not only scientific, but also how to write the applications to obtain grants in Romania, mainly from The Academy of Medical Sciences and The National Council for Higher Education Scientific Research (in Romanian Consiliul Naţional al Cercetării Ştiinţifice din Învăţământul Superior, abbreviated as CNCSIS). Using funding from such grants I succeeded to buy an NMR spectrometer and an ESR spectrometer produced at IFA Bucureşti-Măgurele. In addition, Petre T. Frangopol helped us in setting up the laboratory for work with radioactive compounds at the new DCB of UMF Cluj-Napoca.

Petre T. Frangopol played an important role in helping the collaboration with an American group led by Professor Fred A. Kummerow (Chief of Burnsides Research Laboratory, University of Illinois at Urbana-Champaign). He was a chemist interested in the medical effects of nutrition and became famous as he discovered the atherogenic effects of trans fatty acids. I performed my first research visit to USA invited by Fred Kummerow. We organized in New York a workshop supported by The New York Academy of Sciences (Kummerow et al., 1983) and later we obtained a grant from the National Science Foundation (NSF) for collaborative work.

With the money from this grant we bought the radioactive compound with which we performed the crucial experiment proving the presence in the human $\mathrm{RBC}$ membrane of a water channel protein (later called aquaporin1). Ross Holmes, one of Fred Kummerow's coworkers, came to Cluj-Napoca and collaborated with us in the crucial experiment. The results were reported in two landmark papers published in 1986 by the Gh. Benga's group in well known international journals in USA (Benga et al., 1986a) and in Europe (Benga et al., 1986b). I reviewed our work in several publications in the following years (Benga, 1988, 1989, 2003, 2006, 2012). In 1988 the protein was rediscovered by an American group led by Peter Agre in Baltimore, who purified by chance the protein, calling it CHIP28 (CHannel forming integral membrane protein of $28 \mathrm{kDa}$ ) having no idea of its function (Denker et al., 1988). Only in 1992 the American group discovered the function of that protein as a water channel (Preston et al., 1992); however, they have not cited the two papers previously published by Benga's group (Benga, 1988, 1989). In 2003, Peter Agre was awarded the Nobel Prize in Chemistry, which he shared with Roderick MacKinnon for their ,discoveries concerning structure and function of channels in cell membranes".

Professor Petre T. Frangopol fully supported the campaign for the recognition of the priority of Gh. Benga's group in the discovery of the first water channel protein before Peter Agre and for the recognition that Gh. Benga was omitted from the 2003 Nobel Prize in Chemistry (Frangopol \& Gavrilă, 2005; Frangopol, 2006b). Petrache came to ClujNapoca to participate in all scientific events I organized over almost five decades, including The Two World Congresses on Water Channel Proteins (Aquaporins and Relatives) Celebrating the Discovery of the First Water Channel Protein (Later Called Aquaporin 1), Cluj-Napoca, Romania, 27-29 October 2011, and 6-10 May 2015, respectively. He gave the Opening Plenary Lecture at „The Second World Congress on Water Channel Proteins" (May 2015). This was just one of Petrache's efforts to support the campaign for the 
recognition of my priority in the discovery of the first water channel protein (later called aquaporin1). Similar opinions were expressed by many scientists. Among these were: (a) several hundred young Romanian scientists (most of them working abroad), members of Ad Astra Association (AAA), who signed on-line a document prepared by $A A A$ leadership; (b) members of The R.A. and academics working at several universities in Romania or abroad, even leading universities, faculties, departments (Balaban et al., 2006; Căproiu, 2006; Cucuianu, 2006; Gozariu, 2006; Haulică, 2006; Kuchel, 2006; Popescu, 2013). Some of their comments deserve to be cited.

„In the late 1980s, Peter Agre, while working on the rhesus blood group antigens at Johns Hopkins University serependipitously discovered a new membrane protein that he called CHIP28 (channel integral protein of molecular weight $28 \mathrm{kD}$ ). At the time he had no idea that its function was...Previously and independently, Gheorghe Benga and his group in Romania had shown that the water transport inhibitor $p$-chloromercuribenzene sulfonate selectively bound to a protein in red blood cell membranes... Subsequent studies showed that this was a glycosylated form of CHIP28" (Vandenberg \& Kuchel, 2003).

„The detection of water-specific membrane channels in red blood cells belong to the fundamentals discoveries in biology of the twentieth century...In 1986 and 1988, the independent groups of Gheorghe Benga and Peter Agre, respectively, discovered the water channel proteins which later were called aquaporins" (Wolburg et al., 2011).

„The 2003 Nobel prize in chemistry was awarded for the discovery of ,porins”-protein channels that transport molecules through cell membranes. It went to the Americans Peter Agre for aquaporins, or water channels, and Roderick MacKinnon for potassium channels. But aquaporins were first described in 1986 by Gheorghe Benga, in what was then communist Romania. There is no doubt that Agre told us much more about aquaporins than Benga did, but I can't believe Benga would have been excluded from the award had he been working in a Western nation" (Cox, 2014).

Additional information regarding the full history of the discovery of aquaporins and the contributions of Gh. Benga may be found in references: Benga (2014), Frangopol (2002, 2005, 2007, 2015, 2018), Iftimovici (2015) and Marin (2018).

Of note, the great scientist, Romanian born, George Emil Palade (1974 Nobel Laureate in Physiology of Medicine) sent on December 2003 a message by fax (to the number of „Iuliu Haţieganu” University of Medicine and Pharmacy Cluj-Napoca) supporting the recognition of the priority of Gh. Benga:

„Dear Doctor Benga,

I did not expect The Nobel Committee for Chemistry to select water channels as area to give prominence this year and I did not realize either how close is your work to that of Peter Agre.

The idea of a petition has the merit of attracting the attention to the scientific community in the regrettable mistake of your omission from the group of laureates this year. ...

In any case I signed the petition received from you, I wish you enough courage and strength to carry through this battle and I remain sincerely,

George E. Palade"

Based on his experience at IFA, Petre T. Frangopol was invited from 1991 to 1999 as Professor of Biophysics and Medical Physics at the University "Alexandru Ioan Cuza" (UAIC) Iaşi. He received nothing in terms of spaces and funding of laboratories, since the UAIC leaders claimed that funding received from the Ministry of Education was provided only for existing sections (not for a new one). Based on his experience 
from București-Măgurele, P.T. Frangopol obtained annual finances from the Ministry of Research in Romania for his two new laboratories at UAIC: one was the Laboratory of Medical Physics (the first such laboratory in Romania), and the other was the Laboratory of Biophysics (the second such laboratory after that of the București University). In addition, Professor Frangopol obtained funding (over 500,000 USD) by international competition, from the International Atomic Energy Agency, from the European Union programs (Erasmus, Copernicus) etc. During his tenure at UAIC, Professor Frangopol edited a series of 6 annual volumes (1992-1997) Current Topics in Biophysics, published in English by Iaşi University Press. He invited authors from over 35 Universities and Scientific Institutions from 13 countries to provide scientific literatures for the bachelor's degree students. He also sent his students abroad, to perform the experimental work for their Ph.D. degree in well equipped laboratories, with which scientific collaboration was established. The results were published in international scientific journals. He supported the further development of the graduates of his Section of Biophysics at well-known universities. Some of them became Professors at: Free University of Berlin, Graz University (Austria), Athens University (Greece), Umeå University, Linköping University (Sweden), University College Dublin (Ireland), University of California at Irvine, Stanford University, Texas A\&M University (USA), University of Queensland (Australia) etc.

Petre T. Frangopol continued his academic career from1999 to 2002 at „Babeş-Bolyai” University Cluj-Napoca as Professor of Biophysics and Biophysical Chemistry (Faculty of Chemistry), at "Vasile Goldiş" Western University Arad (Faculty of Medicine) and from 2002 to 2004 at Polytechnica University Bucureşti (Department of Physics). Everywhere, he was highly appreciated for his unique scientific and humane qualities by the colleagues and students alike.

Petre T. Frangopol undertook highly valuable research and scientific activities in many fields: Chemistry, Radiochemistry, Physical Organic Chemistry, Biophysical Chemistry, Biophysics, Medical Physics, Archaeometry, Oceanography, History of Chemistry in Romania. He made an essential contribution in the development of the domain of Science Policy and Scientometrics in Romania. He published a lot of articles and books on the Science Policy and Scientometrics, starting with articles first published in the weekly supplement Aldine of a well-known journal România Liberă. Dozens of interesting articles appeared, having an increasing impact on the Romanians interested in education and research. I was among the scientists to whom he used to send weekly everything he published on these topics. Then Petre T. Frangopol compiled the articles assembling 7 volumes entitled „Mediocrity and Excellence: a radiography of science and education in Romania", published from 2002 to 2019.

In 2012 Petre T. Frangopol became the Editor-in-Chief of Revista de Politica Ştiinţei şi Scientometrie, a journal of The Ministry of Education and Research, actually of the CNC$S I S)$. He coordinated this journal until 2016 when the Ministry cut the financing of the journal. Petre T. Frangopol was Scientific Counselor at CNCSIS. He contributed to making possible the access of Romanian scientists to Science Citation Index, published first by the Institute of Scientific Information of Philadelphia, known as ISI Thomson Reuters. This database is now managed by Clarivate Analytics.

Petre T. Frangopol was member of the Editorial Board of important journals: Revue Roumaine de Chimie, Journal of Radioanalytical and Nuclear Chemistry, Scientometrics. Over the years he initiated and organized or co-organized many scientific events: multidisciplinary seminars at IFA; four national conferences of the chemical physics program (1986-1989, Iaşi, Cluj-Napoca, Bucureşti); the 8th workshop „Balkan Days of Biochemistry and Biophysics", organized for the first time in Romania, Cluj-Napoca, 1990, with 
Vasile V. Morariu; two Romanian Conferences on the Application of Physics Methods in Archaeology, Cluj-Napoca (1987, 1989, with volumes published each time); seminars on Romanian original drugs (procain-based drugs, Gerovital $\mathrm{H}_{3}$, and Aslavital, Trofopar and Boicil), some lectures being published in special issues of Revue Roumaine de Biochimie and in other journals (Frangopol \& Mihailescu, 2001; Ionescu et al., 1987; Morariu et al., 1987; Popescu et al., 1988; Tomoaia-Cotisel et al., 1997, 2000; Zsako et al., 1994).

Petre T. Frangopol was a prolific author. A recent search on the web showed that he was author, editor, redactor of dozens of publications (articles, conference proceedings, biographies, in 3 languages) which are found in 98 library holdings.

The achievements of Petre T. Frangopol were recognized by many prizes and distinctions: the "Constantin Miculescu" Prize of R.A. (1990, for his work on the biophysics of the interaction of Romanian drugs with cellular membranes), the "Horia Hulubei" Diploma (2006, for his outstanding contribution to the development of IFA), Honorary Professor of The "Iuliu Haţieganu" University of Medicine and Pharmacy ClujNapoca (2008), the Great Honor Diploma of the National Comission of Archeometry (1997, awarded by the National Museum of History of Transylvania, Cluj-Napoca), the Diploma of Honor of the National Institute of Marine Research (Constanţa), Diploma of Excellence awarded by the University of Bucharest (2018), Honorary Citizen of Constanţa (2019). Petre Frangopol was also a member of the German Chemical Society (since 1971), of the Romanian Chemical Society, and of the Romanian Biophysical Society.

Petre T. Frangopol was elected Honorary Member of R.A. in 2012. He certainly deserved to become Member of R.A. many years before. I was very pleased to sustain Petre T. Frangopol on the occasion of the R.A. Meeting when he was discussed. I answered to some querries formulated by venerable members present in the Aula (who were surprized by the many achievements of Petre T. Frangopol). Subsequently, as a Member of R.A., P.T. Frangopol proved his value, expressing many a time overtly thoughtful opinions on important matters of the Academy's life (including opinions regarding the candidates for the Academy's leadership). He was nominated by the Section of Chemical Sciences to coordinate the writing of the ample volume on the "History of Romanian Chemistry", published in 2018 by the Romanian Academy Publishing House in the jubilee series on the Romanian Civilization. He did a wonderful job (Frangopol, 2018).

Petre T. Frangopol fully supported the campaign for the recognition of merits of my group and of Vasile V. Morariu's group from the first moment he met us and until the death of Vasile and of himself. Petre T. Frangopol made a wonderful presentation of Vasile V. Morariu in the book in which he presented the achievements of Romanian mathematicians, physicists and chemists with outstanding results (Frangopol, 2004). I was very honored to write the Preface to the book. Vasile and myself wrote a short presentation of the Romanian Biophysics Research School founded by Professor Petre T. Frangopol (Morariu \& Benga, 2013). Unfortunately, Vasile's file has not been even discussed by the Section of Biological Sciences of R.A. while he was alive! I was very happy to help in the election of Vasile as Member of The Academy of Romanian Scientists).

I will be grateful to Petre T. Frangopol all my life, considering not only the scientific publications we accomplished, but also for the support and competent advice he gave me along the decades. P.T. Frangopol (Petrache) will be greatly missed by many academics, scientists, former students, friends, and by all who had the pleasure of interacting with him over several decades. I also express again deep regrets for the greatest 
loss of his life, the death of his beloved wife, Mioara Frangopol, after a long incurable illness. As Petrache confessed at the Meeting of R.A. dedicated to his 85th anniversary cellebrated on October 8, 2018, all his achievements are linked to Mioara. She had an exceptional professional training and a brilliant mind and helped him in all activities. Mioara stood shoulder to shoulder to Petrache for 58 years until she passed into eternity. She put her whole life at the service of the harmony of their marriage and of his career.

Acknowledgements I thank Casa Cărții de Știință, Cluj-Napoca (Mircea Trifu, Director and Dr. Marius Mureșan, Redactor \& Associated Staff Member, "Babeş-Bolyai" University Cluj-Napoca), for sending me the pdf of P.T. Frangopol's last book (Frangopol, 2019). I also deeply thank to the daily newspaper ZIUA de Constanţa and Mrs. Adriana ROȘU (Editorial Secretary) for sending me the photograph of P. T. Frangopol and the agreement to be published in Scientometrics.

\section{References}

Anghel, S. (Coordinator) (2019). Academic Dobrogea. Ex Ponto (in Romanian).

Balaban, A. T. (2012). Brief review of contributions to experimental organic chemistry. Revue Roumaine De Chimie, 57(6), 535-557. in Romanian.

Balaban, A. T., Frangopol, P. T., Mărculescu, M., \& Bally, I. (1961). Factors affecting stability and equilibria of free radicals: Steric factors in hydrazyls. Tetrahedron, 13(4), 258-267.

Balaban, A. T., Haiduc, I., Matasa, C., \& Sha'afi, R. I. (2006). Who discovered the water channels (aquaporins). Cellular and Molecular Biology (noisy-Le-Grand), 52(7), 6-7.

Benga, Gh. (1985). Protein-lipid interactions in biological membranes. In Gh. Benga (Ed.), Structure and properties of cell membranes, Vol. I. A survey of molecular aspects of membrane and function (pp. 160-188). CRC Press.

Benga, Gh. (1988). Water transport in red blood cell membranes. Progress in Biophysics and Molecular Biology, 51, 193-245.

Benga, Gh. (1989). Membrane proteins involved in the water permeability of human erythrocytes: Binding of $p$-chloromercuribenzene sulphonate to membrane proteins correlated with nuclear magnetic resonance measurements. In Gh. Benga (Ed.), Water transport in biological membranes (Vol. II, pp. 41-62). CRC Press.

Benga, Gh. (2003). Birth of water channel proteins-the aquaporins. Cell Biology International, 27, 701-709.

Benga, Gh. (2006). Water channels (aquaporins and relatives): Twenty years after their discovery in ClujNapoca, Romania. Acta Endocrinologica (Bucharest), 2(3), 323-335.

Benga, Gh. (2012). Water channels (aquaporins and relatives). Molecular Aspects of Medicine (special Issue), 33(5-6), 514-517.

Benga, Gh. (2014). Aquaporinology. Acta Endocrinologica (Bucharest), 10(1), 1-8.

Benga, Gh., \& Chapman, D. (1976). Protein-lipid interactions in biomembranes. I. Albumin-liposome model system-Spin label studies. Revue Roumaine De Biochimie, 13(4), 251-261.

Benga, Gh., Dânşoreanu, I. C., Frangopol, M., \& Frangopol, P. T. (2008). Some applications of spin labels the study of serum albumin and biological membranes. Revista De Chimie, 59(11), 1255-1259. in Romanian.

Benga, Gh., Hodârnău, A., Ionescu, M., Pop, V. I., Frangopol, P. T., Strujan, V., Holmes, R. P., \& Kummerow, F. A. (1983a). A comparison of the effects of cholesterol and 25-hydroxy-cholesterol on egg yolk lecithin liposomes: spin label studies. In F. A. Kummerow, Gh. Benga, \& R. P. Holmes (Eds.), Biomembranes and cell function (Vol. 414, pp. 140-152). Annals of New York Academy of Sciences.

Benga, Gh., \& Holmes, R. P. (1984). Interactions between components in biological membranes and their implication for membrane function. Progress in Biophysics \& Molecular Biology, 43(3), 195-258.

Benga, Gh., Ionescu, M., Popescu, O., \& Pop, V. I. (1983b). Effect of chlorpromazine on proteins in human erythrocyte membranes as inferred from spin labeling and biochemical analyses. Molecular Pharmacology, 23(3), 771-778.

Benga, Gh., \& Morariu, V. V. (1977). Membrane defect affecting water permeability in human epilepsy. Nature, 265(5595), 636-638. 
Benga, Gh., Pop, V. I., Ionescu, M., Hodârnău, A., Tilinca, R., \& Frangopol, P. T. (1983c). Comparison of human and rat liver microsomes by spin label and biochemical analyses. Biochimica Et Biophysica Acta, 750(1), 194-199.

Benga, Gh., Popescu, O., Borza, V., Pop, V. I., Mureșan, A., Mocsy, I., Brain, A., \& Wrigglesworth, J. M. (1986b). Water permeability of human erythrocytes. Identification of membrane proteins involved in water transport. European Journal of Cell Biology, 41, 252-262.

Benga, Gh., Popescu, O., Pop, V. I., \& Holmes, R. P. (1986a). p-(Chloromercuri)benzenesulfonate binding by membrane proteins and the inhibition of water transport in human erythrocytes. Biochemistry, 25(7), 1533-1538.

Benga, Gh., \& Strach, S. J. (1975). Interpretation of ESR spectra of nitroxide-maleimide-labelled proteins and the use of this technique in the study of albumin and biomembranes. Biochimica Et Biophysica Acta, 400(1), 69-79.

Braun, T., \& Maxim, I. (1961). Radiation effects on Lithium-dopped Nickel oxide catalysts in carbon monoxide oxidation. Nature, 192(480), 548-549.

Braun, T., Maxim, I., \& Galateanu, I. (1958). Radiometric titration with complexons. Nature, 182(4640), 936-937.

Căproiu, M. T. (2006). The 2003 Nobel Prize in chemistry eluded the Romanian chemist Gheorghe Benga. Revista De Chimie, 57(4), 439-443.

Chiotan, C., Dema, I., Frangopol, P. T., Gîrd, E., \& Voicu, V. (1961). The preparation of ${ }^{131}$ I of high specific activity. Revista De Chimie, 12(12), 706-707. in Romanian.

Cox, G. (2014). Opinion letters. New Scientist, 30, 26.

Cucuianu, M. (2006). The discovery by Gh. Benga of the first water channel protein in 1985 in ClujNapoca, Romania, a few years before P. Agre (2003 Nobel Prize in Chemistry). Romanian Journal of Internal Medicine, 44(3), 323-334.

Denker, B. M., Smith, B. L., Kuhaida, F. P., \& Agre, P. (1988). Identification, purification and partial characterization of a novel Mr 28,000 integral membrane protein from erythrocytes and renal tubules. Journal of Biological Chemistry, 263(30), 15634-15642.

Forrester, A. J., Hay, J. M., \& Thomson, R. H. (1968). Organic chemistry of stable free radicals. Academic Press.

Frangopol, P. T. (2002). The 70th aniversary of Profesor Tibor Braun. Revista De Chimie (bucureşti), 53, 651-652. in Romanian.

Frangopol, P. T. (2004). Elites of researchers from Romania. Mathematics-Physics-Chemistry. Casa Cărţii de Ştiinţă. in Romanian.

Frangopol, P. T. (2005). Hirsch Index-A new scientometric indicator. Academica, XVI, 70-72. in Romanian.

Frangopol, P. T. (2006a). LAUDATIO Professor Tibor Braun. Revista De Politica Științei Și Scientometrie - Serie Nouă, 4(2), 129-135. in Romanian.

Frangopol, P. T. (2006b). Gheorghe BENGA excluded from The Nobel Prize, the founder of Cell and Molecular Biology in Cluj-Napoca. Revista De Politica Științei Și Scientometrie - Serie Nouă, 4(1), 8-15. in Romanian.

Frangopol, P.T. (2007). A young boy age 75! In W. Glänzel (Editor-in-Chief). The multidimensional world of Tibor Braun. A multidisciplinary encomium for his 75th Birthday. Special volume of the e-zine of the International Society of Scientometrics and Informatics, vol. 03-S, March 2007, p. 7.

Frangopol, P. T. (Coordinator) (2018). History of Romanian chemistry. Editura Academiei Române (in Romanian).

Frangopol, P. T. (2012). Horia Hulubei. Revista De Politica Științei Și Scientometrie. Serie Nouă, 1 , 178-183. in Romanian.

Frangopol, P. T. (2015). Interview with Academician Tibor Braun, founder of the international journal Scientometrics. Revista De Politica Științei Și Scientometrie - Serie Nouă, 4, 8-15. in Romanian.

Frangopol, P. T. (2019). Mediocrity and excellence-A radiography of science and education in Romania (Vol. 7). Casa Cărţii de Ştiinţă. in Romanian.

Frangopol, P. T., Frangopol, M., \& Baikan, R. (1973). New aryl-tert-alkylnitroxyls. Bulletin of the Academy of Sciences of the USSR, Division of Chemical Science, 24(11), 2392-2396.

Frangopol, P. T., \& Gavrilă, L. (2005). Memorandum regarding the discovery of the first water channel protein by Gheorghe Benga in Romania, a few years before Peter Agre (2003 Nobel Prize in Chemistry). Romanian Journal of Genetics, 1(2), 101-102.

Frangopol, P. T., \& Mihailescu, D. (2001). Interactions of some local anesthetics and alcohols with membranes. Colloids and Surfaces B-Biointerfaces, 22(1), 3-22.

Galateanu, I., Maxim, I., \& Braun, T. (1960). Radiometric titration of Zinc and Copper with EDTA. Fresenius' Zeischrift Für Analytische ChemIe, 172(4), 274-279. 
Gozariu, L. (2006). Comments on the discovery of water channels, selected for the 2003 Nobel Prize in chemistry, and the regrettable omission of Gheorghe Benga. Acta Endocrinologica (Bucharest), 2, $377-380$.

Haulică, I. (2006). A regrettable mistake in the award of the Nobel Prize in chemistry: the omission of Gheorghe Benga, the first discoverer of the water channel protein in the red blood cell membrane. Cellular and Molecular Biology (noisy-Le-Grand), 52(7), 8-9.

Iftimovici, R. (2015). The universal history of medicine and pharmacy. Second edition revised and added (p. 552). Editura Academiei Române. in Romanian.

Ionescu, M. S., Frangopol, P. T., Ghitescu, M., \& Marcu, I. (1987). Effects of procaine on the rheological behaviour of normal and pathological human red blood cells. Revue Roumaine De Biochimie, 24(2), 177-184.

Kuchel, P. W. (2006). The story of the discovery of aquaporins: Convergent evolution of ideas-But who got there first. Cellular and Molecular Biology (noisy-Le-Grand), 52(7), 2-5.

Kummerow, F. A., Benga, Gh., \& Holmes, R. P. (1983). Biomembranes and cell function. Annals of New York Academy of Sciences, USA, 414, 140-152.

Marin, F. (2018). Faculty of Medicine, Cluj medical school and hospitals from Cluj (1500-2000) (2nd ed., pp. 972-1000). Casa Cărţii de Ştiinţă. in Romanian.

Maxim, I., \& Braun, T. (1963). Effects of reactor radiations on chemisorption equilibrium of oxygen on Nickel Oxide. Journal of Physical Chemistry of Solids, 24(4), 537-548.

Maxim, I., Braun, T., \& Galateanu, I. (1959). Phase separation through flotation in radiometric titration. Journal of Inorganic \& Nuclear Chemistry, 10(1-2), 166-168.

Morariu, V. V., \& Benga, Gh. (1977). Evaluation of a nuclear magnetic resonance technique for the study of water exchange through erythrocyte membranes in normal and pathological subjects. Biochimica Et Biophysica Acta, 469(3), 301-310.

Morariu, V. V., \& Benga, Gh. (2013). A Romanian biophysics research school founded by Professor Petre T. Frangopol. Romanian Journal of Biophysics, 23(4), 263-266.

Morariu, V. V., Ionescu, M. S., Frangopol, M., Grosescu, R., \& Lupu, M. (1987). Procaine hydrochloride effect on the diffusional water exchange through human erythrocyte membranes. Revue Roumaine De Biochimie, 24(2), 149-154.

Nachman, M., Maxim, I., \& Braun, T. (1961). Radiation induced chemisorption of oxygen on Chromia. Journal of Physical Chemistry of Solids, 20(3-4), 307-314.

Nonhebel, D. C., \& Walton, J. C. (1974). Free-radical chemistry-structure and mechanism. Cambridge University Press.

Popescu, O. (2013). Revista de Politica Științei și Scientometrie - Serie nouă, 2, 154-158 (in Romanian).

Popescu, L. M., Frangopol, M., \& Frangopol, P. T. (1988). Procaine inhibits the protein-kinase c-dependent phosphorylation of membrane cytoskeletal proteins in human erythrocytes. Revue Roumaine De Biochimie, 25(3), 193-197.

Preston, G. M., Caroll, T. P., Guggino, W. B., \& Agre, P. (1992). Appearance of water channels in Xenopus oocytes expressing red blood cell CHIP28 protein. Science, 256(5055), 385-387.

Rozantzev, E. G. (1970). Free nitroxyl radicals. Plenum Press.

Rozantzev, E. G. (1972). Dolgojivuşcie radicali. Nauka.

Sholle, V. D., Kagan, ESh., Michailov, V. J., Rozantsev, E. G., Frangopol, P. T., Frangopol, M., Pop, V. I., \& Benga, Gh. (1980). A new spin label for SH groups in proteins: The synthesis and some applications in labelling of albumin and erythrocyte membranes. Revue Roumaine De Biochimie, 17(4), 291-298.

Tomoaia-Cotisel, M., Oproiu, T., Zsako, J., Mocanu, A., Frangopol, P. T., \& Quinn, P. J. (2000). Numerical analysis of compression isotherms of distearoyl monogalactosyl glycerol monolayers. Revue Roumaine De Chimie, 45(9), 851-861.

Tomoaia-Cotisel, M., Zsako, J., Chifu, E., Mocanu, A., Frangopol, P. T., \& Quinn, P. J. (1997). Procaine binding to stearic acid monolayers spread at the air/buffer interface. The Influence of $p H$ and Surface Pressures, Journal of Romanian Colloid Surfaces Chemistry Association, 2(3-4), 30-36.

Vandenberg, J. I., \& Kuchel, P. W. (2003). Nobel Prizes for magnetic resonance imaging and channel proteins. Medical Journal of Australia, 179, 611-613.

Wolburg, H., Wolburg-Bucholz, K., Fallier-Becker, K., Noel, S., \& Mack, A. (2011). Structure and functions of aquaporin-4-based orthogonal arrays of particles. International Review of Cellular and Molecular Biology, 287, 1-41.

Zsako, J., Tomoaia-Cotisel, M., Chifu, E., Mocanu, A., \& Frangopol, P. T. (1994). Procaine interactions with phospholipid monolayers at the air/water interface. Gazzetta Chimica Italiana, 124, 5-9. 